Our Nature
Journal homepage: http://nepjol.info/index.php/ON

\title{
Early winter avifaunal diversity from Buxa Tiger Reserve and Rasikbeel Wetland Complex of northern part of West Bengal, India
}

\author{
Sagar Adhurya, Moitreyee Banerjee, Achintya Kumar Pal and Utpal Singha Roy* \\ Department of Zoology, Durgapur Government College, JN Avenue, Durgapur- 713214, Burdwan, West Bengal, \\ India, ${ }^{*}$ E-mail: srutpal@gmail.com
}

\begin{abstract}
The present study was carried out to record the avifaunal diversity and abundance in and around Buxa Tiger Reserve (Raja Bhat Khawa, Buxa Fort, Raimatang and Jayanti) and Rasikbeel Wetland Complex, situated at the northern part of West Bengal, India during $19^{\text {th }}-22^{\text {nd }}$ November, 2013. A total of 60 bird species belonging to 31 families were identified during four days of study period of which 8 were winter migrants, one was summer migrant and rest were resident. Anthropogenic interventions have altered much of the natural habitat of the present study location; however, a healthy avifaunal diversity was recorded during the present study. More intensive investigations will certainly enrich our knowledge of avian diversity and distribution pattern from the present study location leading to the proper conservation of this important bird area.
\end{abstract}

Key words: Avifauna, Biodiversity, Habitat heterogeneity

DOI: http://dx.doi.org/10.3126/on.v14i1.16439

Manuscript details: Received: 11.04.2015 / Accepted: 21.03.2016

Citation: Adhurya, S., M. Banerjee, A.K. Pal and U.S. Roy 2016. Early winter avifaunal diversity from Buxa Tiger Reserve and Rasikbeel Wetland Complex of northern part of West Bengal, India. Our Nature 14(1): 39-46. DOI: http://dx. doi.org/10.3126/on.v14i1.16439

Copyright: ( ) Adhurya et al. 2016. Creative Commons Attribution-NonCommercial 4.0 International License.

\section{Introduction}

Bird diversity study acts as an intrinsic tool to monitor habitat types both qualitatively and quantitatively (Bilgrami, 1995). Anthropogenic interventions have incessantly altered and destroyed natural habitat throughout the world and consequently reduced overall avifaunal diversity (Rapoport, 1993). Moreover, changes in climatic conditions in recent decades have been unanimously reported to influence bird diversity most negatively (Sekercioglu et al., 
2012). India with 88 threatened bird species is presently ranked at seventh position in the IUCN Red List of endangered birds (BirdLife International, 2010).

The northern part of West Bengal comprises a number of sanctuaries, national parks, reserve forests and wetlands supporting enormous biodiversity (Islam and Rahmani, 2004). Buxa Tiger Reserve (BTR) (National Park) and Rasikbeel Wetland Complex (RBWC) are two such most important areas that harbour large numbers of local and migratory birds (Islam and Rahmani, 2004). However, escalating threat from anthropogenic activities especially tourism pressure has altered much of the natural habitat of the present study location. Thus it was most imperative to prepare a checklist of birds of these regions that are subjected to various degrees of pressures from human disturbances.

\section{Materials and methods}

The present study was conducted in two different habitat types Buxa Tiger Reserve $\left(26^{\circ} 39^{\prime} \mathrm{N}, 89^{\circ} 34^{\prime} 48^{\prime \prime} \mathrm{E}\right)$ and Rasikbeel Wetland Complex $\left(26^{\circ} 21^{\prime} \mathrm{N}, 89^{\circ} 40^{\prime} \mathrm{E}\right)$ located in the northern part of West Bengal (Figs. $1-2)$.

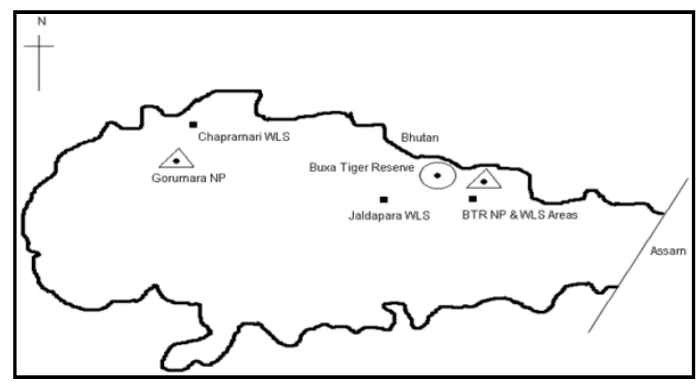

Figure 1. Map (without scale) of District Jalpaiguri showing Buxa Tiger Reserve, National Park and Wildlife Sanctuary Areas.

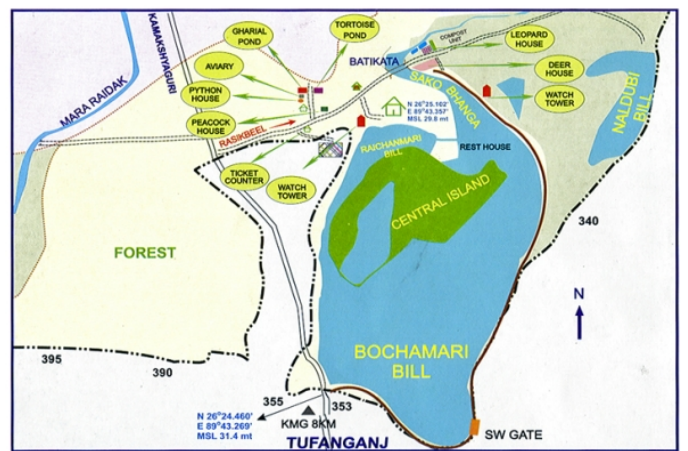

Figure 2. Map (without scale) of Rasikbeel Wetland Complex.

Buxa Tiger Reserve (BTR), in the Alipurduar Sub-Division of Jalpaiguri District was setup as the $15^{\text {th }}$ Tiger Reserve in the country in 1983 at the northeastern corner of West Bengal bordering Bhutan and Assam. The present studies were conducted at or near Raja Bhat Khawa, Buxa Fort, Raimatang and Jayanti of BTR. The area of the BTR encompasses $760.87 \mathrm{Km}^{2}$ having a sanctuary of $269 \mathrm{~km}^{2}$ and a National Park of $117.01 \mathrm{~km}^{2}$ of pristine forests and is situated in the transition zone between Biome-8 (Sino-Himalayan Subtropical Forest) and Biome-12 (Indo-Gangetic Plain) (Islam and Rahmani, 2004). This reserve has distinct habitat division into zones like Tarai (transitional zone between forest belt and cultivated plains characterized by the presence of reeds and grasses), Bhabar (narrow forest belt characterized with complete absence of water sources) and hilly landscape mounts with an altitude of $1800 \mathrm{~m}$ and is crisscrossed by numerous rivers and rivulets. IBA site code of this region is IN-WB01 with A1 and A2 criteria. Fraction of this IBA also falls within the Eastern Himalayas Endemic Bird Area (EBA 130) which consists of 21 restricted range species (Stattersfield et al., 1998). According to Champion and Seth (1968) BTR has eight Sub-types. 
The main floral and faunal composition of this forest are trees like Sal (Shorea robusta), Gamar (Gmelian arborea), Simul (Bombax sp.) and Chikrasi (Chukrasia tabularis) and animals like Asian Elephant (Elephas maximus), Tiger (Panthera tigris), Gaur (Bos gaurus), Wild boar (Sus scrofa) and Sambar (Cervus unicolor). This IBA supports handsome avifaunal diversity. Wildlife Institute of India, Deharadun reported 523 bird species from this site. Inglis et al. (1918-1920) summarized the vertebrates list from Jalpaiguri District. Stevens (1923-1925) recorded a number of new species from Raidak River while Inglis (1952-1969) has given details of some avian species from Buxa area. Law (1953) and Sanyal (1995) each have recorded one new bird species from Buxa area. Allen et al. (1996) have recorded 227 birds from BTR while Prakash et al. (2001) have dealt with the role of avifauna as indicator species from BTR. Sivakumar and Prakash (2004) have recorded waterbirds within BTR while Sivakumar et al. (2006) have reported 22 new bird species from BTR. Roy et al. (2012) have reported 68 bird species from this forest area.

Rasikbeel Wetland Complex (RBWC) is the largest wetland complex in Coochbehar district of West Bengal covering around $18.40 \mathrm{Km}^{2}$ of area of which wetland occupies almost $1.78 \mathrm{Km}^{2}$ areas. According to The Ministry of Environment and Forests (MoEF), Government of India Rasikbeel is among the 94 identified wetlands of national importance, many of which are protected areas (NWCP, 2009). The vast wetland complex comprises variable sized water bodies namely, Rasikbeel, Nildoba Beel, Raichangmari Beel, Bochamari Beel and some others. The nature of the beels is of oxbow lake and formed by meandering of Raidak, Sakobhanga and Ghoramara River. The floral composition of Rasikbeel includes Sal (Shorea robusta), Teak (Tectona grandis), Gammar (Gmelina arborea), Khair (Bauhinia purpurea), Arjun (Terminalia arjuna), Simul (Bombax sp.) etc. along with a number of wetland plants. The faunal diversity recorded from this area comprises 13 species of mammals, 165 birds, 7 reptiles, 5 amphibians, 49 fishes, 3 molluscs and more than 15 species of butterflies. Rasikbeel also hosts a rescue center for Leopard (Panthera pardus), Python (Python sp.), Gharial (Gavialis gangeticus), Spotted Deer (Axis axis), tortoise, birds and small rodents recognized by central zoo authority.

Birds were counted following the point count method (Sutherland, 2006). Distances were recorded in terms of concentric zones around the point (eg. $30 \mathrm{~m}, 50$ $\mathrm{m}, 100 \mathrm{~m}$ ) up to the visible limit. Bird density was calculated following formula: $\check{\mathrm{D}}=$ $\left(\mathrm{n}_{1}+\mathrm{n}_{2} / \pi \mathrm{r}^{2} \mathrm{~m}\right) \log _{\mathrm{e}}\left(\mathrm{n}_{1}+\mathrm{n}_{2} / \mathrm{n}_{2}\right)$ [where, $\mathrm{r}=$ radius of concentric zone from the point of observation ( $30 \mathrm{~m}$ and $50 \mathrm{~m}) ; \mathrm{n}_{1}=$ number of birds counted within $\mathrm{r} ; \mathrm{n}_{2}=$ number of birds counted beyond $r ; m=$ number of replicate counts (6 in this case)]. Strategic point counts were conducted during the first two hours after sunrise (0600-0800 hr), during noon (1100-1300 hr) and in the evening $(1600-1800 \mathrm{hr})$ between the $19^{\text {th }}$ November and $22^{\text {nd }}$ November 2013 from the two study location. Six replicate point readings (at least $200 \mathrm{~m}$ apart for continuous 10 minutes) were recorded during the two hours of survey in the morning, during noon and in the evening and were summed up for the cumulative value. Sampling was done for two continuous days before moving to the next study location. The birds were identified using Olympus 8x40 DPS I 
binoculars and field guides of Grewal et al. (2002), Kazmierczak and Perlo (2000), Grimmett et al. (2011) and Ali (2012).

\section{Results and discussion}

During the short span of the present study 60 species of bird belonging to 31 families were recorded. Of these, 45 bird species were recorded from BTR and 37 were recorded form Rasikbeel Wetland Complex. Both the study sites had 23 bird species in common. 8 winter migrants were found from the RBWC during the study period, of which Lesser Adjutant (Leptoptilos javanicus) is considered vulnerable under IUCN threatened category version 3.1 (BirdLife International, 2013). A summer migrant Dark-sided Flycatcher (Muscicapa sibirica) was seen in BTR though its abundance was low. A checklist of the observed bird species is given below (Tab. 1).

Birds are always related to folklore, religion and culture of India. Study of bird diversity gives an estimate of the overall biodiversity of a region, as it occupies almost any habitat (Furness and Greenwood, 1993). Even they respond quickly to any kind of environmental change in and around their habitat and serve as good bioindicators (Padoa-Schioppa et al. 2006).

In recent times conservation of biodiversity has become the most talked about subject (Ehrlich and Wilson, 1991) and with increasing rates of anthropogenic effects on biodiversity at global as well as regional scale framing of conservation strategies is the biggest challenge. Since holistic inventory of diversity needs impossible levels of time and effort (Lawton et al., 1998) scientists around the globe most recently have emphasized on performing rapid inventories (Pearson, 1994; Chakravarthy and Sridhar, 1995; Roy et al.,
2011). Short span biodiversity surveys are gaining importance nowadays and rapid checklist are prepared (Chakravarthy and Sridhar, 1995; Roy et al., 2011).

The present study recorded 60 species of birds from the two regions surveyed on a short span. A previous record from these two regions depicted 68 species from BTR and 75 from RBWC itself (Roy et al., 2012). Allen et al. (1996) have recorded about 227 species of bird from the entire range of BTR while Sivakumar et al. (2006) have recorded 284 bird species during their study period. Considering the short study span in the present investigation it was obvious that less bird diversity was observed, however, mention may be made that due to habitat fragmentation and degradation avian diversity along with other biodiversity is alarmingly decreasing from this pristine forest area of West Bengal. Rasikbeel Wetland Complex, considered as an abode of winter wetland birds are also suffering from anthropogenic interventions, resulting in gradual decrease of avifaunal diversity which needs serious attention.

Presently almost all preserved areas are confronting major anthropogenic disturbances like urbanization, tourist pressure, livelihood dependence (mainly in the form of cattle grazing and fuel wood collection) and pollution (Islam and Rahmani, 2004; Mallick, 2010; Karmakar, 2011). Since British Raj a broad region of the forests has been converted to monoculture land of timber producing trees. Moreover, forests have been cleared off for making space for tea gardens and other types of cultivation purposes. To add salt to the wound poaching of wild animals and timber smuggling are major issues for North Bengal forests like most other parts of India. Natural calamities like forest fire 
Adhurya et al. / Our Nature (2016), 14 (1): 39-46

Table 1. Checklist of birds found in the present study along with their migration status and IUCN threatened category.

\begin{tabular}{|c|c|c|c|c|c|c|}
\hline \multicolumn{2}{|c|}{ SN Common name } & Scientific name & BTR & RBWC & Migration status & IUCN category \\
\hline \multicolumn{7}{|c|}{ Order: Passeriformes } \\
\hline \multicolumn{7}{|c|}{ Family: Chloropseidae } \\
\hline 1 & Golden-fronted Leafbird & Chloropsis aurifrons & $\mathrm{B}$ & - & $\mathrm{R}$ & $\mathrm{LC}$ \\
\hline \multicolumn{7}{|c|}{ Family: Muscicapidae } \\
\hline 2 & Grey-headed Canary-flycatcher & Culicicapa ceylonensis & $\mathrm{E}$ & - & $\mathrm{W}$ & $\mathrm{LC}$ \\
\hline 3 & Oriental Magpie-robin & Copsychus saularis & $\mathrm{B}$ & $\mathrm{B}$ & $\mathrm{R}$ & $\mathrm{LC}$ \\
\hline 4 & White-capped Water-redstart & Phoenicurus leucocephalus & $\mathrm{E}$ & - & $\mathrm{R}$ & $\mathrm{LC}$ \\
\hline 5 & Dark-sided Flycatcher & Muscicapa sibirica & $\mathrm{E}$ & - & $\mathrm{S}$ & $\mathrm{LC}$ \\
\hline 6 & Taiga Flycatcher & Ficedula albicilla & A & A & W & $\mathrm{LC}$ \\
\hline \multicolumn{7}{|c|}{ Family: Campephagidae } \\
\hline 7 & Long-tailed Minivet & Pericrocotus ethologus & B & - & W & $\mathrm{LC}$ \\
\hline 8 & Large Cuckooshrike & Coracina macei & $\mathrm{C}$ & - & $\mathrm{R}$ & $\mathrm{LC}$ \\
\hline \multicolumn{7}{|c|}{ Family: Sturnidae } \\
\hline 9 & Common Myna & Acridotheres tristis & A & A & $\mathrm{R}$ & $\mathrm{LC}$ \\
\hline 10 & Asian Pied Starling & Gracupica contra & $\mathrm{A}$ & $\mathrm{A}$ & $\mathrm{R}$ & $\mathrm{LC}$ \\
\hline 11 & Jungle Myna & Acridotheres fuscus & $\mathrm{B}$ & $\mathrm{B}$ & $\mathrm{R}$ & $\mathrm{LC}$ \\
\hline 12 & Hill Myna & Gracula religiosa & A & - & $\mathrm{R}$ & $\mathrm{LC}$ \\
\hline 13 & Chestnut-tailed Starling & Sturnia malabarica & A & A & $\mathrm{R}$ & $\mathrm{LC}$ \\
\hline \multicolumn{7}{|c|}{ Family: Dicruridae } \\
\hline 14 & Black Drongo & Dicrurus macrocercus & A & A & $\mathrm{R}$ & $\mathrm{LC}$ \\
\hline 15 & Hair-crested Drongo & Dicrurus hottentottus & - & $\mathrm{D}$ & $\mathrm{R}$ & $\mathrm{LC}$ \\
\hline 16 & Lesser Racket-tailed Drongo & Dicrurus remifer & $\mathrm{C}$ & $\mathrm{C}$ & $\mathrm{R}$ & $\mathrm{LC}$ \\
\hline 17 & Greater Racket-tailed Drongo & Dicrurus paradiseus & $\mathrm{D}$ & - & $\mathrm{R}$ & $\mathrm{LC}$ \\
\hline \multicolumn{7}{|c|}{ Family: Pycnonotidae } \\
\hline 18 & Red-vented Bulbul & Pycnonotus cafer & $\mathrm{B}$ & $\mathrm{B}$ & $\mathrm{R}$ & $\mathrm{LC}$ \\
\hline 19 & Red-whiskered Bulbul & Pycnonotus jocosus & $\mathrm{B}$ & $\mathrm{B}$ & $\mathrm{R}$ & $\mathrm{LC}$ \\
\hline 20 & Black-crested Bulbul & Pycnonotus flaviventris & $\mathrm{C}$ & - & $\mathrm{R}$ & $\mathrm{LC}$ \\
\hline \multicolumn{7}{|c|}{ Family: Oriolidae } \\
\hline 21 & Black-hooded Oriole & Oriolus xanthornus & $\mathrm{B}$ & - & $\mathrm{R}$ & $\mathrm{LC}$ \\
\hline \multicolumn{7}{|c|}{ Family: Corvidae } \\
\hline 22 & House Crow & Corvus splendens & A & A & $\mathrm{R}$ & $\mathrm{LC}$ \\
\hline 23 & Eastern Jungle Crow & Corvus levaillantii & - & $\mathrm{C}$ & $\mathrm{R}$ & $\mathrm{LC}$ \\
\hline 24 & Rufous Treepie & Dendrocitta vagabunda & $\mathrm{B}$ & $\mathrm{C}$ & $\mathrm{R}$ & $\mathrm{LC}$ \\
\hline \multicolumn{7}{|c|}{ Family: Artamidae } \\
\hline 25 & Ashy Woodswallow & Artamus fuscus & $\mathrm{D}$ & - & $\mathrm{R}$ & $\mathrm{LC}$ \\
\hline \multicolumn{7}{|c|}{ Family: Timaliidae } \\
\hline 26 & Jungle Babbler & Turdoides striata & - & $\mathrm{B}$ & $\mathrm{R}$ & $\mathrm{LC}$ \\
\hline \multicolumn{7}{|c|}{ Family: Laniidae } \\
\hline 27 & Brown Shrike & Lanius cristatus & $\mathrm{C}$ & - & W & $\mathrm{LC}$ \\
\hline 28 & Long-tailed Shrike & Lanius schach & $\mathrm{D}$ & - & $\mathrm{R}$ & $\mathrm{LC}$ \\
\hline \multicolumn{7}{|c|}{ Family: Motacillidae } \\
\hline 29 & White Wagtail & Motacilla alba & - & $\mathrm{C}$ & $\mathrm{W}$ & $\mathrm{LC}$ \\
\hline 30 & Grey Wagtail & Motacilla cinerea & $\mathrm{D}$ & - & W & $\mathrm{LC}$ \\
\hline \multicolumn{7}{|c|}{ Family: Irenidae } \\
\hline 31 & Asian Fairy-bluebird & Irena puella & $\mathrm{D}$ & - & $\mathrm{R}$ & $\mathrm{LC}$ \\
\hline \multicolumn{7}{|c|}{ Order: Coraciiformes } \\
\hline \multicolumn{7}{|c|}{ Family: Alcedinidae } \\
\hline 32 & White-throated Kingfisher & Halcyon smyrnensis & A & A & $\mathrm{R}$ & $\mathrm{LC}$ \\
\hline 33 & Stork-billed Kingfisher & Pelargopsis capensis & - & $\mathrm{B}$ & $\mathrm{R}$ & $\mathrm{LC}$ \\
\hline 34 & Common Kingfisher & Alcedo atthis & - & $\mathrm{B}$ & $\mathrm{R}$ & $\mathrm{LC}$ \\
\hline \multicolumn{7}{|c|}{ Family: Coraciidae } \\
\hline 35 & Indian Roller & Coracias benghalensis & $\mathrm{B}$ & $\mathrm{B}$ & $\mathrm{R}$ & $\mathrm{LC}$ \\
\hline Fam & y: Meropidae & & & & & \\
\hline 36 & Little Green Bee-eater & Merops orientalis & - & A & $\mathrm{R}$ & $\mathrm{LC}$ \\
\hline
\end{tabular}


Adhurya et al. / Our Nature (2016), 14 (1): 39-46

\begin{tabular}{|c|c|c|c|c|c|c|}
\hline \multicolumn{7}{|c|}{ Family: Columbidae } \\
\hline 37 & Rock Pigeon & Columba livia & A & A & $\mathrm{R}$ & $\mathrm{LC}$ \\
\hline 38 & Eurasian Collared Dove & Streptopelia decaocto & B & - & $\mathrm{R}$ & $\mathrm{LC}$ \\
\hline 39 & Spotted Dove & Stigmatopelia chinensis & A & A & $\mathrm{R}$ & $\mathrm{LC}$ \\
\hline \multicolumn{7}{|c|}{ Order: Bucerotiformes } \\
\hline \multicolumn{7}{|c|}{ Family: Bucerotidae } \\
\hline 40 & Oriental Pied Hornbill & Anthracoceros albirostris & $\mathrm{C}$ & - & $\mathrm{R}$ & $\mathrm{LC}$ \\
\hline \multicolumn{7}{|c|}{ Order: Falconiformes } \\
\hline \multicolumn{7}{|c|}{ Family: Accipitridae } \\
\hline 41 & Black Kite & Milvus migrans & A & - & $\mathrm{R}$ & $\mathrm{LC}$ \\
\hline 42 & Griffon Vulture & Gyps fulvus & $\mathrm{D}$ & - & W & $\mathrm{LC}$ \\
\hline 43 & Black Eagle & Ictinaetus malayensis & - & $\mathrm{C}$ & $\mathrm{R}$ & $\mathrm{LC}$ \\
\hline \multicolumn{7}{|c|}{ Order: Ciconiiformes } \\
\hline \multicolumn{7}{|c|}{ Family: Ardeidae } \\
\hline 44 & Indian Pond-heron & Ardeola grayii & A & A & $\mathrm{R}$ & $\mathrm{LC}$ \\
\hline 45 & Black-crowned Night-heron & Nycticorax nycticorax & $\mathrm{C}$ & - & $\mathrm{R}$ & $\mathrm{LC}$ \\
\hline 46 & Cattle Egret & Bubulcus ibis & A & A & $\mathrm{R}$ & $\mathrm{LC}$ \\
\hline 47 & Little Egret & Egretta garzetta & $\mathrm{C}$ & $\mathrm{B}$ & $\mathrm{R}$ & $\mathrm{LC}$ \\
\hline \multicolumn{7}{|c|}{ Family: Ciconiidae } \\
\hline 48 & Lesser Adjutant & Leptoptilos javanicus & - & $\mathrm{C}$ & $\mathrm{R}$ & VU \\
\hline \multicolumn{7}{|c|}{ Order: Galliformes } \\
\hline \multicolumn{7}{|c|}{ Family: Phasianidae } \\
\hline 49 & Red Junglefowl & Gallus gallus & $\mathrm{D}$ & - & $\mathrm{R}$ & $\mathrm{LC}$ \\
\hline 50 & Indian Peafowl & Pavo cristatus & $\mathrm{C}$ & - & $\mathrm{R}$ & $\mathrm{LC}$ \\
\hline \multicolumn{7}{|c|}{ Order: Gruiformes } \\
\hline \multicolumn{7}{|c|}{ Family: Rallidae } \\
\hline 51 & Common Moorhen & Gallinula chloropus & - & A & $\mathrm{R}$ & $\mathrm{LC}$ \\
\hline 52 & White-breasted Waterhen & Amaurornis phoenicurus & - & $\mathrm{B}$ & $\mathrm{R}$ & $\mathrm{LC}$ \\
\hline \multicolumn{7}{|c|}{ Order: Anseriformes } \\
\hline \multicolumn{7}{|c|}{ Family: Anatidae } \\
\hline 53 & Cotton Pygmy-goose & Nettapus coromandelianus & - & A & $\mathrm{R}$ & $\mathrm{LC}$ \\
\hline \multicolumn{7}{|c|}{ Order: Charadriiformes } \\
\hline \multicolumn{7}{|c|}{ Family: Jacanidae } \\
\hline 54 & Bronze-winged Jacana & Metopidius indicus & - & A & $\mathrm{R}$ & $\mathrm{LC}$ \\
\hline \multicolumn{7}{|c|}{ Family: Scolopacidae } \\
\hline 55 & Green Sandpiper & Tringa ochropus & - & $\mathrm{D}$ & W & $\mathrm{LC}$ \\
\hline \multicolumn{7}{|c|}{ Order: Piciformes } \\
\hline \multicolumn{7}{|c|}{ Family: Picidae } \\
\hline 56 & Black-rumped Flameback & Dinopium benghalense & $\mathrm{B}$ & B & $\mathrm{R}$ & $\mathrm{LC}$ \\
\hline 57 & Fulvous-breasted Woodpecker & Dendrocopos macei & - & $\mathrm{D}$ & $\mathrm{R}$ & $\mathrm{LC}$ \\
\hline \multicolumn{7}{|c|}{ Family: Ramphastidae } \\
\hline 58 & Blue-throated Barbet & Psilopogon asiaticus & $\mathrm{B}$ & $\mathrm{B}$ & $\mathrm{R}$ & $\mathrm{LC}$ \\
\hline \multicolumn{7}{|c|}{ Order: Cuculiformes } \\
\hline \multicolumn{7}{|c|}{ Family: Cuculidae } \\
\hline & Green-billed Malkoha & Phaenicophaeus tristis & $\mathrm{E}$ & - & $\mathrm{R}$ & $\mathrm{LC}$ \\
\hline$\overline{\text { Or }}$ & Apodiformes & & & & & \\
\hline & y: Apodidae & & & & & \\
\hline 60 & House Swift & Apus nipalensis & $\mathrm{B}$ & $\mathrm{C}$ & $\mathrm{R}$ & $\mathrm{LC}$ \\
\hline
\end{tabular}

$(\mathrm{BTR}=$ Buxa Tiger Reserve, RBWC $=$ Rasikbeel Wetland Complex, A-E $=$ Relative abundance of the bird species, where A used for species more likely observed and $\mathrm{E}$ used for species rarely observed I the present study, $\mathrm{R}$ $=$ Resident, $\mathrm{W}=$ Winter Migrant, $\mathrm{S}=$ Summer Migrant, $\mathrm{LC}=$ Least Concerned, $\mathrm{VU}=$ Vulnerable) 
also have disastrous effects on wildlife from the present study locations (Islam and Rahmani, 2004).

To sum up the present study reveals a healthy state for bird diversity, but alarming conditions are also prevailing at the same time. A rapid decrease in diversity in this region can be well accredited to the deteriorating habitat conditions and disturbance pressure. Prakash et al. (2001) have already recognized monoculture plantations, tea gardens, tree cutting, firewood collection, grass cutting, fires and cattle grazing as the major threats to birds in this parts of the world. Ever growing railways through the forest patches can also be considered as an added threat to the overall diversity of this region. Thus prevention and protection along with proper conservation strategies are the best solutions to the present problem.

\section{Acknowledgements}

The authors thankfully acknowledge the help and support extended by the Director of Public Instruction Government of West Bengal, India. The present work was carried out as a part of field studies following the guidelines of University of Burdwan by the B.Sc. Zoology (Honours) students of Durgapur Government College, for partial fulfillment of the course. The students were introduced to different field sampling and survey techniques during this study tour. The authors hereby acknowledge the help of the B.Sc. Zoology students who actively participated in completing this field based study.

\section{References}

Ali, S. 2012. The book of Indian Birds. Bombay Natural History Society, Oxford University Press.

Allen, D., J. Anderton and K. Kazmierczak 1996. Report on an ornithological visit to Buxa Tiger
Reserve, West Bengal, India, 17 February to 6 March 1992. Forktail 12: 47-64.

Bilgrami, K.S. 1995. Concept and conservation of biodiversity. CBS Publishers and distributors, Delhi.

BirdLife International 2010. IUCN Red List for birds. http://www.birdlife.org

Chakravarthy, A.K. and S. Sridhar 1995. Bird diversity and conservation. Ornithology Society of India. Bangalore.

Champion, H.G. and S.K. Seth 1968. A revised survey of the forest types of India. Government of India, New Delhi.

Ehrlich, P.R. and E.O. Wilson 1991. Biodiversity studies: Science and policy. Science 253: 758 762.

Furness, R.W. and J.J.D. Greenwood 1993. Birds as a monitor of environmental change. Chapman and Hall, London.

Grewal, B., B. Harvey and O. Pfister 2002. A photographic guide to the birds of India. Princeton University Press.

Grimmett, R., C. Inskipp and T. Inskipp 2011. Birds of India. Princeton University Press.

Inglis, C.M. 1952-1959. Birds of the Duars. J. Bengal Nat. Hist. Soc. 25: 71-76, 121-127, 164-169, 196200; 26: 1-8, 47-56, 93-99, 149-156; 27: 9-12, $55-58,83-95,129-155 ; 28: 18-51,102-115,149-$ 161; 29: 16-25, 88-94, 150-160; 30: 35-42, 8197, 166-181; 31: 14-32, 49-60; 32: 1-9, 69-73; 33: 121-125, 181-184; 34: 1-4, 85-87; 35: 1-5, 49-63.

Inglis, C.M., W.L. Travers and H.V. O'Donel 1918 1920. A tentative list of the vertebrates of the Jalpaiguri District, Bengal. Journal of Bombay Natural History Society 24: 988-999; 27: 151-162.

Islam, M.Z. and A.R. Rahmani 2004. Important bird area in India: Priority sites for conservation. IBCN, Bombay Natural History Society, BirdLife International, UK.

Karmakar, M. 2011. Ecotourism and its impact on the regional economy - a study of North Bengal (India). Tourismos: An International Multidisciplinary Journal of Tourism 6(1): 251-270.

Kazmierczak, K. and B.V. Perlo 2000. A field guide to the Birds of the Indian Subcontinent. Yale University Press.

Law, S.C. 1953. Occurrence of the Smew [Mergellus albellus (Linn.)] in West Bengal. Journal of Bombay Natural History Society 51: 508-509.

Lawton, J.H., D.E. Bignell, B. Bolton, G.F. Bloemers, P. Eggleton, P.M. Hammond, M. Hodda, R.D. Holt, T.B. Larsen, N.A. Mawdsley, N.E. 
Stork, D.S. Srivastava and A.D. Watt 1998. Biodiversity inventories, indicator taxa, and effects of habitat modification in tropical forest. Nature 391: 72-76.

Mallick, J.K. 2010. Past and present status of the Indian Tiger in northern West Bengal, India: an overview. Journal of Threatened Taxa 2(3): 739952.

NWCP (National Wetland Conservation Programme) 2009. Guidelines for conservation and management of wetlands in India. Conservation and Survey Division, Ministry of Environment and Forests, Government of India, New Delhi.

Padoa-Schioppa, E., M. Baietto, R. Massa and L. Bottoni 2006. Bird communities as bioindicators: The focal species concept in agricultural landscapes. Ecological Indicators 6(1): 83-93.

Pearson, D.L. 1994. Selecting indicator taxa for the quantitative assessment of biodiversity. Philosophical Transactions of the Royal Society of London B 345: 75-79.

Prakash, V., S. Sivakumar and J. Verghese 2001. Avifauna as indicators of habitat quality in Buxa Tiger Reserve. Quarterly Report IV. Bombay Natural History Society, Mumbai.

Rapoport, E.H. 1993. The process of plant colonization in small settlements and large cities. In $\mathrm{Hu}$ mans as components of ecosystems (MacDonell, M.J. and S. Pickett eds.). Springer-Verlag, New York. pp. 190-207.

Roy, U.S., A. Pal, P. Banerjee and S.K. Mukhopadhyay 2011. Comparison of avifaunal diversity in and around Neora Valley National Park, West Bengal, India. Journal of Threatened Taxa 3(10): 2136-2142.

Roy, U.S., P. Banerjee and S.K. Mukhopadhyay 2012. Study on avifaunal diversity from three different regions of North Bengal, India. Asian Journal of Conservation Biology 1(2): 120-129.

Sanyal, P. 1995. Rare crane of India. Journal of Bombay Natural History Society 91: 453.

Sekercioglu, C.H., R.B. Primack and J. Wormworth 2012. The effects of climate change on tropical birds. Biological Conservation 148: 1-18.

Sivakumar, S. and V. Prakash 2004. Waterbirds of Buxa Tiger Reserve, West Bengal. Zoos' Print Journal 19(4): 1451-1452.

Sivakumar, S., J. Varghese and V. Prakash 2006. Abundance of birds in different habitats in Buxa Tiger Reserve, West Bengal, India. Forktail 22: 128-133.

Stattersfield, A.J., M.J. Crosby, A.J. Long and D.C. Wege 1998. Endemic Bird areas of the World: Priorities for biodiversity conservation. BirdLife Conservation Series No. 7. BirdLife International, Cambridge, U.K.

Stevens, H. 1923-1925. Notes on the birds of the Sikkim Himalayas. Journal of Bombay Natural History Society 29: 503-518, 723-740, 10071030; 30: 54-71, 352-379, 664-685, 872-893.

Sutherland, W.J. 2006. Ecological Census Techniques a handbook. Cambridge University Press, New York. 432 p. 